Archives of Agriculture and Environmental Science

\title{
In vitro propagation of two strawberry (Fragaria ananassa Duch.) cultivars of Bangladesh
}

\author{
Tapati Roy* (D) , S.M. Abdullah AI Mamun and Md. Monirul Islam
}

Agrotechnology Discipline, Khulna University, Khulna-9208, BANGLADESH

${ }^{*}$ Corresponding author's E-mail: tapatiroytopu@gmail.com

\section{ARTICLE HISTORY}

Received: 24 September 2018

Revised received: 30 September 2018

Accepted: 01 October 2018

\section{Keywords}

BARI strawberry

Benzyl adinopurine (BAP)

Kinetin (Kin)

Modern strawberry

\begin{abstract}
An experiment on in vitro propagation of strawberry was carried out at Plant Breeding and Biotechnology Laboratory of Agrotechnology Discipline, Khulna University, Khulna, Bangladesh during the period of February to November, 2015. In the experiment, runners of two strawberry cultivars viz. BARI Strawberry ${ }^{-1}$ and Modern Strawberry-5 (Festival) were cultured on MS media supplemented with different concentrations of BAP (1.0, 1.5 and 2.0 $\left.\mathrm{mgL}^{-1}\right)$ and $\mathrm{Kin}\left(0.1,0.5\right.$ and $\left.1.0 \mathrm{mgL}^{-1}\right)$ for multiple shoot regeneration. The experiment was laid out in Completely Randomized Design (CRD) with three replications. The highest number of shoots (10.41) was obtained from Modern Strawberry-5 and maximum shoot length (13.62 $\mathrm{mm}$ ) obtained from BARI Strawberry-1. Maximum number of shoots (13.33) and shoot length $\left(24.29 \mathrm{~mm}\right.$ ) were recorded from MS media containing $1.0 \mathrm{mgL}^{-1} \mathrm{BAP}$ and $1.0 \mathrm{mgL}^{-1} \mathrm{Kin}$. Then all the regenerated plantlets were cultured on $\mathrm{MS}$ media containing $2.0 \mathrm{mgL}^{-1} \mathrm{IAA}$ for root initiation. Greater reduction in vigor was observed in Modern Strawberry-5 (Festival) when they were transferred to root induction media. Ex vitro survivability of the complete plantlets varied from 36.67 to $6.67 \%$. Maximum survivability of both varieties $36.67 \%$ (BARI Strawber$\mathrm{ry}^{-1}$ ) and $26.67 \%$ (Festival) were recorded from MS media supplemented with $1.0 \mathrm{mgL}-1 \mathrm{BAP}$ and $1.0 \mathrm{mgL}^{-1} \mathrm{Kin}$. For in vitro micropropagation, BARI Strawberry-1 may be better and MS media supplemented with $1.0 \mathrm{mgL}^{-1} \mathrm{BAP}$ and $1.0 \mathrm{mgL}^{-1} \mathrm{Kin}$ may be better.
\end{abstract}

(C)2018 Agriculture and Environmental Science Academy

Citation of this article: Roy, T., Abdullah Al Mamun, S.M. and Islam, M.M. (2018). In vitro propagation of two strawberry (Fragaria ananassa Duch.) cultivars of Bangladesh, Archives of Agriculture and Environmental Science, 3(4): 382-387, https:// dx.doi.org/10.26832/24566632.2018.030409

\section{INTRODUCTION}

Strawberry (Fragaria ananassa Duch.) is a widely grown plant species of the genus Fragaria, belonging to the family Rosaceae. Strawberry is stoloniferous herb and perennial in growth habit. The promising fruit strawberry is widely appreciated due to its characteristic aroma, bright red color, juicy texture and sweetness. Strawberry is rich in several lifesaving proteins as well as vitamin A, C and E, folic acid, selenium, calcium, polyfenol, alagic, feralic and kumaric acid and cuertcitin, janthomycin and phytostebol. Some of these nutrients can prevent cancer and AIDS (Manganaris et al., 2014).

Strawberry is a major berry crop around the world. It has been commercially cultivated in many counties in the world.
In Bangladesh, the cultivation of strawberry was started commercially after the year 2000. Strawberry cultivation is mainly concentrated in northern districts of Bangladesh (Biswas et al., 2007). Its cultivation may be extended in the south-western coastal districts as well but for this, an uninterrupted and quality plantlet supply is very important. In this area cultivation of strawberry has been gaining popularity in recent years. But farmers are suffering from unavailability of quality planting materials. The saplings, available to them, are very often less vigorous or prone to disease infestation. When they cultivate such type of saplings, naturally they cannot harvest expected amount of yield. So to make strawberry as a popular commercial crop in south-western region of Bangladesh, it is an urgent need to ensure quality saplings at due time to the farmers. 
Strawberry plants are rarely propagated by seeds; rather, they are generally propagated by cutting off runners or by in vitro clonal propagation (commonly known as in vitro micropropagation) (Moradi et al., 2011). In conventional method, strawberry plants grow continuously in the field infested largely by diseasepests; thereby reduce vigor as well as fruit quality and yield. The in vitro culture of nodal cutting has been successful in the clonal propagation of strawberry plants. Micropropa-gated strawberry plants are comparatively better in different characters (crown size, number of runners, flowering time and yield of berries) than conventionally propagated runner plants (Karhu and Hakala, 2007). In addition, the storage of tissue cultured propagules requires less space than traditional runner plants and the in vitro storage can be initiated at any time during the production cycle (Swartz et al., 1981). Although tissue culture protocol for strawberry propagation is a well-established fact but still there exist some delimiting factors. Skilled manpower is very important for this sector. Again, all the genotypes do not respond equally to in vitro clonal propagation and the hormonal requirements also varies from genotype to genotype to establish culture for the mass production of plant propagules. In this context the present experiment was conducted with a view to optimizing the concentration of growth regulators for in vitro clonal propagation of two strawberry cultivars of Bangladesh.

\section{MATERIALS AND METHODS}

The experiment was carried out at Plant Breeding and Biotechnology Laboratory, Agrotechnology Discipline, Khulna University, Khulna, Bangladesh from February to November, 2015.

\section{Treatments and design of the experiment}

For the research, two cultivars of strawberry viz. BARI (Bangladesh Agricultural Research Institute) Strawberry-1 and Modern Strawberry-5 (Festival) were selected and MS media supplemented with nine treatments consisting of different concentrations and combinations of BAP and Kin were as follows: 1) $1.0 \mathrm{mgL}^{-1} \mathrm{BAP}$ and $0.1 \mathrm{mgL}^{-1} \mathrm{Kin}$, 2) $1.5 \mathrm{mgL}^{-1} \mathrm{BAP}$ and $0.1 \mathrm{mgL}^{-1} \mathrm{Kin}$, 3) $2.0 \mathrm{mgL}^{-1} \mathrm{BAP}$ and $0.1 \mathrm{mgL}^{-1} \mathrm{Kin}$, 4) 1.0 $\mathrm{mgL}^{-1} \mathrm{BAP}$ and $0.5 \mathrm{mgL}^{-1} \mathrm{Kin}$, 5) $1.5 \mathrm{mgL}^{-1} \mathrm{BAP}$ and $0.5 \mathrm{mgL}^{-1}$ Kin, 6) $2.0 \mathrm{mgL}^{-1} \mathrm{BAP}$ and $0.5 \mathrm{mgL}^{-1} \mathrm{Kin}$, 7) $1.0 \mathrm{mgL}^{-1} \mathrm{BAP}$ and 1.0 $\mathrm{mgL}^{-1} \mathrm{Kin}$, 8) $1.5 \mathrm{mgL}^{-1} \mathrm{BAP}$ and $1.0 \mathrm{mgL}^{-1} \mathrm{Kin}$, 9) $2.0 \mathrm{mgL}^{-1} \mathrm{BAP}$ and $1.0 \mathrm{mgL}^{-1} \mathrm{Kin}$. The experiment was laid out in Completely Randomozed Design (CRD) with three replications. There were total 18 treatment combinations in each replications.

\section{Collection of strawberry cultivars}

BARI Strawberry-1 was collected from Ankur nursery, Jessore and Modern Strawberry-5 (Festival) was collected from Modern Horticultural Center, Nator. These collected plant materials (Germplasm) were grown and conserved in the field Laboratory (BARI Strawberry-1) of Agrotechnology Discipline and in the field of Plant Breeding and Biotechnology Laboratory (Modern
Strawberry-5 (Festival)) of Agrotechnology Discipline, Khulna University, Khulna. Shoot (runner) tips of the both varieties were used as explant.

Media for shoot multiplication and root initiation

Full strength MS (Murashige and Skoog, 1962) media supplimented with BAP (1.0, 1.5 and $2.0 \mathrm{mgL}^{-1}$ ) and Kin ( 0.1, 0.5 and $1.0 \mathrm{mgL}^{-1}$ ) were used for in vitro shoot multiplication. MS media supplemented with $2.0 \mathrm{mgL}^{-1}$ IAA was used for rooting of the in vitro grown shoots.

\section{Collection and preparation of explant culture}

Fresh runners from healthy field grown strawberry plants were collected from the fields of Plant Breeding and Biotechnology Laboratory, Agrotechnology Discipline, Khulna University, Khulna. The runner tips (about $2.0 \mathrm{~cm}$ ) were separated by scissors and washed for five times throughly under running tap water to remove the dusts. The tips were then treated with with few drops of Tween-20 for 10 minutes followed by shaking with $0.05 \mathrm{gL}^{-1} \mathrm{NADCC}$ at $37^{\circ} \mathrm{C}$ for three hours in shaking incubator at $70 \mathrm{pv}$ (shake/minute). The runner tips were then transferred to laminar airflow cabinet and washed with autoclave distilled water for 3 times. They were then sterilized with $70 \%$ ethanol for 30 seconds followed by $0.2 \% \mathrm{HgCl}_{2}$ for 8 minutes. Thereafter, they were washed with autoclave distilled water for 3 times to wash out the traces of $\mathrm{HgCl}_{2}$. About 1.5 to $2.0 \mathrm{~cm}$ from shoot tips after surface sterilization, were cultured on MS medium with the help of sterilized forceps into the cultured bootle each containing $30 \mathrm{ml}$ semi-solid medium under laminar airflow hood. After the innoculation, the cultures were kept under fluorescent light in growth chamber with controlled temperature $\left(25 \pm 1^{\circ} \mathrm{C}\right)$ under 16 hours photoperiod with light intensity of 2000-3000 lux and relative humidity $80 \pm 2 \%$ for three weeks to allow multile shoot regenaration. All cultures were checked daily and any culture showing symptoms of contaminations were discarded immediately.

\section{Data collection and calculation of survivability}

In the present experiment, data were collected for evaluation on the following parameters: 1) Number of shoot culture-1, 2) Length of shoot $(\mathrm{mm})$ and 3 ) Survivability (\%). Here, two sub-cultures were done, each at 30 days interval in agarifird MS medium supplemented with same concentrations of BAP and Kin. Data on shoot number and shoot length per culture were recored. After 90 days of first culture, the regenerated multiple shoots were cultured in MS medium containing IAA at the rate of $2.0 \mathrm{mgL}-1$ for root initiation. The regenerated plants were then transferred to small pots containing well prepared soil. They were kept for observation. Data on survivability was then recorded by using the following formula:

Survivability $(\%)=\frac{\text { No.of plants survived after } 3 \text { weeks }}{\text { Total no. plants transferred to pots }} \times 100$ 
Statistical analysis of data

The obtained data of the experiment were analyzed for varience (ANOVA) with the help of computer package program MSTAT-C in computer. Differences among the treatment means were compared by New Duncans Multiple Range Test (DMRT) (Gomez and Gomez, 1984).

\section{RESULTS AND DISCUSSION}

Effect of variety on shoot multiplication and shoot length For in vitro shoot tip culture of strawberry, no significant difference was obtained for shoot regeneration between the at early stage (Table 1), but the multiplication rate of the shoots at the second sub-culture (60 DAC) varied significantly for the varieties whereas they showed no significant variation at first and third sub-culture (30 DAC and $90 \mathrm{DAC}$ ). At $90 \mathrm{DAC}$, the maximum number shoots (10.41) was recorded from Modern Strawberry-5 (Festival) than BARI Strawberry-1 (10.33). Zakaria et al. (2014) investigated adventitious shoot regeneration in three cultivated strawberry plants, i.e., Festival, Sweet Charly and Florida via direct organogenesis using the in vitro micropropagation and revealed significant differences among cultivars. The strawberry varieties showed significant variations in shoot length throughout the culture period in vitro (Table 1). Firstly, (30 and 60 DAC) Modern Strawberry-5 (Festival) produced longer shoots (5.96 and $9.29 \mathrm{~mm}$, respectively) than BARI Strawberry-1 (5.09 and $8.75 \mathrm{~mm}$, respectively). But finally (at 90 DAC), BARI Strawberry-1 produced longer shoots (13.62 $\mathrm{mm}$ ) than Modern Strawberry-5 (Festival) did (12.95 mm).
Zakaria et al. (2014) also found varietal differences in in vitro shoot elongation of strawberry.

Effect of growth regulators on shoot multiplication and shoot length

Plant growth regulators showed significant differences in multiple shoot induction in vitro (Table 2). Among the combinations, highest number of shoot regeneration was obtained from 1.0 $\mathrm{mgL}^{-1} \mathrm{BAP}+1.0 \mathrm{mgL}^{-1} \mathrm{Kin}$ at $60 \mathrm{DAC}$ (8.00) and $90 \mathrm{DAC}$ (13.33) but at 30 DAC (3.67) from $2.0 \mathrm{mgL}^{-1} \mathrm{BAP}+0.5 \mathrm{mgL}^{-1} \mathrm{Kin}$ (Table 2). The number of shoots after 30,60 and 90 days of culture varied from 2.00 to $3.67,4.83$ to 8.00 and 8.67 to 13.33 , respectively. Rahman et al. (2015) found the highest shoot regeneration (93.33\%) and number of shoots (15.00) leaf ${ }^{-1}$ disc from MS medium supplemented with $3.0 \mathrm{mgL}^{-1} \mathrm{BAP}$ and $0.5 \mathrm{mgL}$ ${ }^{-1}$ GA3. Hasan et al. (2010) found highest number of usable shoot at the concentration of $1.0 \mathrm{mgL}^{-1} \mathrm{BA}$ with $0.1 \mathrm{mgL}^{-1} \mathrm{NAA}$. Zobayer et al. (2011) obtained the maximum shoots of RABI Strawberry-3 from $0.5 \mathrm{mgL}^{-1} \mathrm{BA}+1.0 \mathrm{mgL}^{-1}$. Sakila et al. (2007) showed that nodal segments of strawberry gave rise to multiple shoots when cultured on MS medium supplemented with different concentration of BA with KIN or GA3 and the highest response of shoot multiplication was obtained in $\mathrm{MS}$ containing $1.5 \mathrm{mgL}^{-1} \mathrm{BA}+0.5 \mathrm{mgL}^{-1} \mathrm{KIN}$.

The length of multiple shoots of strawberry in vitro differed significantly at different concentrations of growth regulators (Table 2). The highest length of shoot at every stage of culture obtained from the concentration of $1.0 \mathrm{mgL}-1 \mathrm{BAP}+1.0 \mathrm{mgL}^{-1}$ Kin. The maximum lengths of shoot at 30,60 and 90 DAC were

Table 1. Number of shoots and length of shoot of strawberry as influenced by variety In vitro.

\begin{tabular}{lcccccc}
\hline \multirow{2}{*}{ Variety } & \multicolumn{3}{c}{$\begin{array}{c}\text { Number of shoots Days after culture } \\
\text { (DAC) }\end{array}$} & \multicolumn{2}{c}{$\begin{array}{c}\text { Length of shoot (mm) Days after culture } \\
\text { (DAC) }\end{array}$} \\
\cline { 2 - 7 } & 30 & 60 & 90 & 30 & 60 & 90 \\
\hline BARI Strawberry-1 & 2.59 & 6.63 & 10.33 & 5.09 & 8.75 & 13.62 \\
Modern Strawberry-5 (Festival) & 2.67 & 5.78 & 10.41 & 5.96 & 9.92 & 12.95 \\
CV & 20.70 & 22.26 & $19.94 \%$ & 7.85 & 5.81 & 5.14 \\
Level of Significance & NS & $*$ & NS & $* *$ & $* *$ & $* *$ \\
\hline
\end{tabular}

NS= Not significant; ${ }^{*}=$ Significant at $5 \%$ level of probability; ${ }^{* *}=$ Significant at $1 \%$ level of probability; CV= Coefficient of Variation

Table 2. Number of shoots and length of shoot of strawberry as influenced by growth regulators In vitro.

\begin{tabular}{lccccccc}
\hline \multicolumn{6}{l}{ Growth Regulators $\left(\mathrm{mgL}^{-1}\right)$} & \multicolumn{4}{c}{ Number of shoots Days after culture (DAC) } & \multicolumn{4}{c}{ Length of shoot (mm) Days after culture (DAC) } \\
\hline BAP & Kin & 30 & 60 & 90 & 30 & 60 & 90 \\
\hline 1.0 & 0.1 & $2.17 \mathrm{bc}$ & $5.33 \mathrm{~b}$ & $9.17 \mathrm{bc}$ & $2.21 \mathrm{~g}$ & $4.09 \mathrm{f}$ & $10.48 \mathrm{e}$ \\
1.5 & 0.1 & $2.33 \mathrm{bc}$ & $4.83 \mathrm{~b}$ & $8.67 \mathrm{c}$ & $3.58 \mathrm{e}$ & $7.10 \mathrm{e}$ & $8.76 \mathrm{f}$ \\
2.0 & 0.1 & $2.50 \mathrm{bc}$ & $5.67 \mathrm{~b}$ & $9.33 \mathrm{bc}$ & $3.98 \mathrm{e}$ & $8.58 \mathrm{~cd}$ & $10.62 \mathrm{e}$ \\
1.0 & 0.5 & $2.00 \mathrm{c}$ & $5.17 \mathrm{~b}$ & $9.50 \mathrm{bc}$ & $6.58 \mathrm{c}$ & $8.65 \mathrm{~cd}$ & $11.62 \mathrm{~d}$ \\
1.5 & 0.5 & $2.67 \mathrm{bc}$ & $6.67 \mathrm{ab}$ & $10.67 \mathrm{bc}$ & $2.85 \mathrm{f}$ & $7.55 \mathrm{e}$ & $11.59 \mathrm{~d}$ \\
2.0 & 0.5 & $3.67 \mathrm{a}$ & $7.83 \mathrm{a}$ & $11.83 \mathrm{ab}$ & $8.01 \mathrm{~b}$ & $9.16 \mathrm{c}$ & $10.99 \mathrm{de}$ \\
1.0 & 1.0 & $2.67 \mathrm{bc}$ & $8.00 \mathrm{a}$ & $13.33 \mathrm{a}$ & $10.63 \mathrm{a}$ & $14.78 \mathrm{a}$ & $24.29 \mathrm{a}$ \\
1.5 & 1.0 & $2.83 \mathrm{~b}$ & $6.00 \mathrm{~b}$ & $10.67 \mathrm{bc}$ & $6.58 \mathrm{c}$ & $12.87 \mathrm{~b}$ & $17.48 \mathrm{~b}$ \\
2.0 & 1.0 & $2.83 \mathrm{~b}$ & $6.33 \mathrm{ab}$ & $10.17 \mathrm{bc}$ & $5.35 \mathrm{~d}$ & $8.42 \mathrm{~d}$ & $13.45 \mathrm{c}$ \\
CV & & 20.70 & 22.26 & 19.94 & 19.94 & $5.81 \%$ & $5.14 \%$ \\
Level of Significance & $* *$ & $* *$ & $* *$ & $* *$ & $*$ \\
LSD & & 0.637 & 1.617 & 2.422 & 2.422 & 0.614 & 0.799 \\
\hline
\end{tabular}

\footnotetext{
${ }^{* *}=$ Significant at $1 \%$ level of probability; $\mathrm{LSD}=$ Least significant difference; $C V=$ Coefficient of Variation
} 
Table 3. Interaction effect of variety and growth regulators on number of shoots and length of shoot of strawberry In vitro.

\begin{tabular}{|c|c|c|c|c|c|c|c|c|}
\hline \multirow[t]{2}{*}{ Variety } & \multicolumn{2}{|c|}{$\begin{array}{l}\text { Growth regulators } \\
\qquad\left(\mathrm{mgL}^{-1)}\right.\end{array}$} & \multicolumn{3}{|c|}{$\begin{array}{c}\text { Number of shoots } \\
\text { Days after culture (DAC) }\end{array}$} & \multicolumn{3}{|c|}{$\begin{array}{l}\text { Length of shoot (mm) } \\
\text { Days after culture (DAC) }\end{array}$} \\
\hline & BAP & Kin & 30 & 60 & 90 & 30 & 60 & 90 \\
\hline \multirow{9}{*}{ BARI Strawberry-1 } & 1.0 & 0.1 & 2.00 & 5.00 & 8.67 & $2.23 \mathrm{jk}$ & $3.17 \mathrm{~g}$ & $13.87 d$ \\
\hline & 1.5 & 0.1 & 2.33 & 4.00 & 7.67 & $1.98 \mathrm{k}$ & $7.10 \mathrm{e}$ & $8.39 \mathrm{~h}$ \\
\hline & 2.0 & 0.1 & 2.33 & 6.33 & 9.67 & $3.95 \mathrm{~h}$ & $9.69 c$ & 10.98 ef \\
\hline & 1.0 & 0.5 & 2.00 & 5.33 & 9.00 & $7.13 \mathrm{~cd}$ & $9.66 \mathrm{c}$ & $11.77 \mathrm{e}$ \\
\hline & 1.5 & 0.5 & 2.67 & 7.33 & 10.67 & $2.59 \mathrm{ijk}$ & $8.00 \mathrm{de}$ & 11.41 ef \\
\hline & 2.0 & 0.5 & 3.67 & 8.33 & 12.00 & 7.00 cde & $8.25 d$ & 11.05 ef \\
\hline & 1.0 & 1.0 & 3.33 & 10.00 & 14.33 & $11.78 \mathrm{a}$ & $15.31 \mathrm{a}$ & $28.48 a$ \\
\hline & 1.5 & 1.0 & 2.33 & 6.67 & 11.00 & $6.25 \mathrm{ef}$ & $10.47 c$ & $17.50 \mathrm{c}$ \\
\hline & 2.0 & 1.0 & 2.67 & 6.67 & 10.00 & $2.97 \mathrm{ij}$ & $7.10 \mathrm{e}$ & $9.15 \mathrm{gh}$ \\
\hline \multirow{9}{*}{ Modern Strawberry-5 (Festival) } & 1.0 & 0.1 & 2.33 & 5.67 & 9.67 & $2.19 k$ & $5.01 \mathrm{f}$ & $7.08 \mathrm{i}$ \\
\hline & 1.5 & 0.1 & 2.33 & 5.67 & 9.67 & $5.22 \mathrm{~g}$ & $7.09 \mathrm{e}$ & $9.14 \mathrm{gh}$ \\
\hline & 2.0 & 0.1 & 2.67 & 5.00 & 9.00 & $4.03 \mathrm{~h}$ & $7.47 \mathrm{de}$ & $10.27 \mathrm{fg}$ \\
\hline & 1.0 & 0.5 & 2.00 & 5.00 & 10.00 & $6.02 \mathrm{f}$ & $7.64 \mathrm{de}$ & 11.47 ef \\
\hline & 1.5 & 0.5 & 2.67 & 6.00 & 10.67 & $3.10 \mathrm{i}$ & 7.08 e & $11.67 \mathrm{e}$ \\
\hline & 2.0 & 0.5 & 3.67 & 7.33 & 11.67 & $9.01 b$ & $10.07 c$ & 10.94 ef \\
\hline & 1.0 & 1.0 & 2.00 & 6.00 & 12.33 & $9.48 b$ & $14.25 \mathrm{~b}$ & $20.10 b$ \\
\hline & 1.5 & 1.0 & 3.33 & 5.33 & 10.33 & $6.90 \mathrm{de}$ & $15.28 \mathrm{a}$ & $17.46 \mathrm{c}$ \\
\hline & 2.0 & 1.0 & 3.00 & 6.00 & 10.33 & $7.73 c$ & $9.73 c$ & $18.34 \mathrm{c}$ \\
\hline CV & & & 20.70 & 22.26 & 19.94 & $7.85 \%$ & $5.81 \%$ & $5.14 \%$ \\
\hline Level of Significance & & & NS & NS & NS & ** & $* *$ & ** \\
\hline LSD & & & 0.901 & 2.287 & 3.425 & 0.718 & 0.868 & 1.130 \\
\hline
\end{tabular}

NS= Not Significant, ${ }^{* *}=$ Significant at $1 \%$ level of probability; LSD= Least significant difference; $C V=$ Coefficient of Variation

10.63, 14.78 and $24.29 \mathrm{~mm}$, respectively (Table 2 ). At 30 and 60 DAC, minimum shoot length (2.21 and $4.09 \mathrm{~mm}$, respectively) was recorded for the MS media having $1.0 \mathrm{mgL}^{-1} \mathrm{BAP}+0.1$ $\mathrm{mgL}^{-1} \mathrm{Kin}$ but finally (at $90 \mathrm{DAC}$ ) the MS media supplemented with $1.5 \mathrm{mgL}^{-1} \mathrm{BAP}+0.1 \mathrm{mgL}^{-1} \mathrm{Kin}$ produced the shortest shoot (8.76) in vitro. Hasan et al. (2010) found highest shoot length from $2.0 \mathrm{mgL}^{-1} \mathrm{BA}+0.2 \mathrm{mgL}-1 \mathrm{NAA}+120 \mathrm{mgL}^{-1}$ adenine. Kosar and Mahmoud (2013) reported maximum shoot length $(52.24$ $\mathrm{mm}$ ) for the medium containing $2.0 \mathrm{mgL}^{-1} \mathrm{BAP}+0.5 \mathrm{mgL}-1 \mathrm{NAA}$. Sakila et al. (2007) recorded the highest average length (34 mm) at the concentration of $1.5 \mathrm{mgL}^{-1} \mathrm{IBA}+0.1 \mathrm{mgL}^{-1} \mathrm{KIN}$.

Interaction effect of variety and growth regulators on shoot multiplication and shoot length

The interaction effect of variety and growth regulators was not significant in in vitro shoot multiplication of strawberry (Table 3). At first sub-culture (30 DAC) Modern Strawberry-5 (Festival) produced more shoots (3.67) than BARI Strawberry-1 (3.33) but at second (60 DAC) and third sub-culture (90 DAC) BARI Strawberry-1 was better ( 10.00 and 14.33 , respectively) than that of Modern Strawberry-5 (Festival) (7.33 and 12.33, respectively). For BARI Strawberry-1, media containing $1.0 \mathrm{mgL}^{-1}$ BAP + 1.0 $\mathrm{mgL}^{-1} \mathrm{Kin}$ produced maximum shoots at all stages but Modern Strawberry-5 (Festival) produced maximum shoots at first (30 $\mathrm{DAC}$ ) and second (60 DAC) sub-culture in the media supplemented with $2.0 \mathrm{mgL}-1 \mathrm{BAP}+0.5 \mathrm{mgL}^{-1} \mathrm{Kin}$ whereas at third sub -culture it produced maximum shoots for the media having 1.0 $\mathrm{mgL}-1 \mathrm{BAP}+1.0 \mathrm{mgL}^{-1} \mathrm{Kin}$. Minimum number of shoots of BARI Strawberry-1 at first (30 DAC) sub-culture (2.00) was obtained from medium containing $1.0 \mathrm{mgL}^{-1} \mathrm{BAP}+0.1 \mathrm{mgL}^{-1} \mathrm{Kin}$ and $1.0 \mathrm{mgL}^{-1} \mathrm{BAP}+0.5 \mathrm{mgL}^{-1}$ and second (60 DAC) and third
(90DAC) sub-culture (4.00 and 7.67, respectively) were recorded from medium containing $1.5 \mathrm{mgL}^{-1} \mathrm{BAP}+0.1 \mathrm{mgL}^{-1} \mathrm{Kin}$. For Modern Strawberry-5, minimum shoots at first (30 DAC) and second (60 DAC) sub-culture (2.00 and 9.00, respectively) were obtained from medium supplemented with $1.0 \mathrm{mgL}-1 \mathrm{BAP}+0.5$ $\mathrm{mgL}^{-1} \mathrm{Kin}$ and $2.0 \mathrm{mgL}^{-1} \mathrm{BAP}+0.1 \mathrm{mgL}^{-1} \mathrm{Kin}$ but medium having $2.0 \mathrm{mgL}^{-1} \mathrm{BAP}+0.1 \mathrm{mgL}^{-1} \mathrm{Kin}$ and $1.0 \mathrm{mgL}^{-1} \mathrm{BAP}+0.5 \mathrm{mgL}^{-1} \mathrm{Kin}$ produced minimum shoots at third sub-culture (90 DAC). Mozafari et al. (2012) observed the best response towards the number of shoot regeneration from meristem explants on $B A$ $1.0 \mathrm{mgL}^{-1}+$ IBA $0.05 \mathrm{mgL}^{-1}+\mathrm{GA} 30.05 \mathrm{mgL}^{-1}$ and this combination showed the best performance of shoot proliferation in cultivars whereas the lowest number on Kin $5 \mathrm{mgL}^{-1}+2$, 4-D 0.5 $\mathrm{mgL}^{-1}+\mathrm{GA} 30.05 \mathrm{mgL}^{-1}$. Zakaria et al. (2014) investigated adventitious shoot regeneration in three strawberry cultivars and revealed that medium containing $2 \mathrm{mgL}^{-1} \mathrm{TDZ}$ was best for regeneration with all the cultivars.

There was a strong and intricate interaction effect of plant growth regulators and strawberry varieties in shoot length in vitro (Table 3). BARI Strawberry-1 produced longer shoots compared to the Modern Strawberry-5 (Festival) at every stage in vitro (Table 3). At 30, 60 and 90 DAC, BARI Strawberry-1 cultured on 1.0 mgL-1 BAP $+1.0 \mathrm{mgL}^{-1} \mathrm{Kin}$ produced higher shoots (11.78, 15.31 and $28.48 \mathrm{~mm}$, respectively). BARI Strawberry-1 at 30 and 90 DAC produced shortest shoot (1.98 and $8.39 \mathrm{~mm}$ respectively) on media containing $1.5 \mathrm{mgL}^{-1} \mathrm{BAP}+0.1$ $\mathrm{mgL}^{-1} \mathrm{Kin}$ and at $60 \mathrm{DAC}$, it produced shortest shoot $(3.17 \mathrm{~mm})$ on media having $1.0 \mathrm{mgL}^{-1} \mathrm{BAP}+0.1 \mathrm{mgL}^{-1} \mathrm{Kin}$. The Modern Strawberry-5 (Festival), at 30 and 90 DAC produced maximum shoot length (9.48 and $20.10 \mathrm{~mm}$, respectively) for the growth regulators combinations of $1.0 \mathrm{mgL}^{-1} \mathrm{BAP}+1.0 \mathrm{mgL}^{-1} \mathrm{Kin}$ and at 
60 DAC produced longest shoot on media having $1.5 \mathrm{mgL}^{-1} \mathrm{BAP}$ $+1.0 \mathrm{mgL}^{-1} \mathrm{Kin}$. This variety produced shortest multiple shoots in the media supplemented with $1.0 \mathrm{mgL}^{-1} \mathrm{BAP}+0.1$ $\mathrm{mgL}^{-1} \mathrm{Kin}$ at every stages in vitro. Zakaria et al. (2014) investigated adventitious shoot regeneration in three cultivated strawberry plants, i.e., Festival, Sweet Charly and Florida and showed that the medium containing $1.5 \mathrm{mgL}^{-1} \mathrm{BA}$ and $0.5 \mathrm{mgL}^{-1} \mathrm{Kin}$ revealed highest elongation efficiency for Festival and Sweet Charly, respectively whereas the medium containing $1.5 \mathrm{mgL}^{-1}$ and $0.1 \mathrm{mgL}^{-1} \mathrm{Kin}$ showed highest elongation efficiency in Florida. Mozafari et al. (2012) observed the best response towards the elongation of shoot on $5 \mathrm{mgL}^{-1} \mathrm{Kin}+0.5 \mathrm{mgL}-12$, 4-D + $0.05 \mathrm{mgL}^{-1} \mathrm{GA} 3$ in cultivars Kurdistan and Merck than 1.0 $\mathrm{mgL}^{-1} \mathrm{BA}+0.05 \mathrm{mgL}^{-1} \mathrm{IBA}+0.05 \mathrm{mgL}^{-1} \mathrm{GA} 3$.

\section{Hardening of regenerated plants}

The regenerated plants from in vitro culture were transferred to small pot containing garden soil, sand and vermicompost (1:1:1) which was prepared earlier. The transferring was done after removal of agar that attached with the roots and treated with antifugal solution Bavistin at the rate of $0.1 \%$. The plants were watered with rain water. After transferring the regenerated plants in pots, they were covered with polythene after spraying water inside it and closed to check evapotranspiration. The pots were kept in hardening room for 7 days under continuous care and then transferred to greenhouse after removal of polythene and kept for 7 days. The pots containing plants were then kept in the net house for 7 days. Data on survivability was then recorded. When regenerated plants transferred to wellprepared soil, great differences were observed in their survivability (Figure 1). Plantlets of BARI Strawberry-1, those were obtained from the multiple shooting media containing $1.0 \mathrm{mgL}^{-1}$ BAP and $1.0 \mathrm{mgL}^{-1}$ Kin showed maximum survivability (36.67\%) and minimum survivability obtained from the media containing $1.5 \mathrm{mgL}^{-1} \mathrm{BAP}$ and $0.5 \mathrm{mgL}^{-1} \mathrm{Kin}$ (10.00\%). On the other hand, maximum (26.67\%) and minimum (6.67\%) survivability of Modern Strawberry- 5 was recorded for the plantlets obtained from the multiple shooting media containing $1.0 \mathrm{mgL}^{-1} \mathrm{BAP}$ and $1.0 \mathrm{mgL}^{-1} \mathrm{Kin} ; 1.5 \mathrm{mgL}^{-1}$ and $1.0 \mathrm{mgL}^{-1}$, respectively. Kosar and Mahmoud (2013) found highest number of regenerated plants obtained MS medium containing $2 \mathrm{mgL}^{-1} \mathrm{BAP}+0.1 \mathrm{mgL}^{-1} \mathrm{NAA}$ in pit mass soil and regenerated plantlets resemble the parent plants morphologically and cytologically when they were shifted to the field condition. Moradi et al. (2011) found that the rooted plants that were transferred to the greenhouse condition, grew, matured and flowered with a survival rate of $100 \%$.

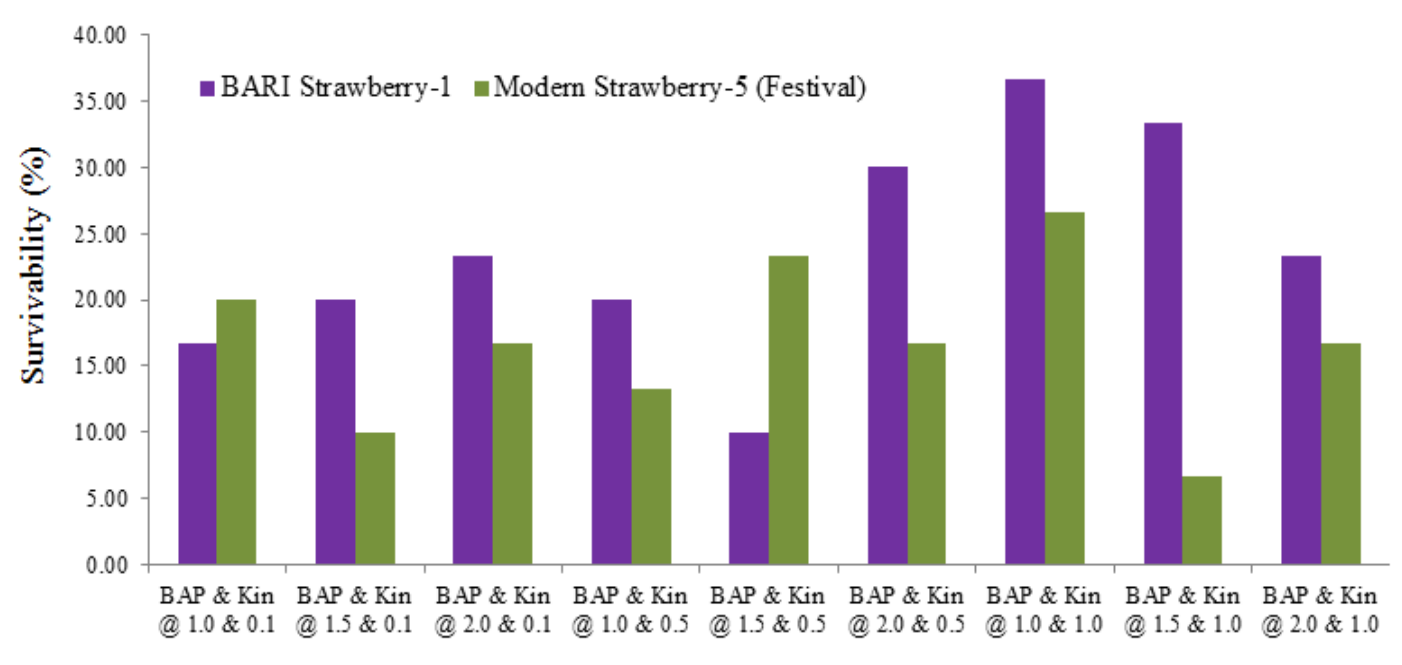

MS media with growth regulators for regeneration

Figure 1. Diagrammatic representation of survivability rate of in vitro grown strawberry.

\section{Conclusion}

For in vitro clonal propagation of strawberry, the maximum number shoots at 90 DAC was recorded 10.41 from Modern Strawberry-5 (Festival) and 10.33 from BARI Strawberry-1. The highest number of shoot regeneration was obtained from MS medium supplemented with growth regulators $1.0 \mathrm{mgL}-1 \mathrm{BAP}+1.0 \mathrm{mgL}-1$ Kin 90 DAC (13.33). The survivability of the regenerated plants varied from $10.00 \%$ to $36.67 \%$ in case of BARI Strawberry-1 and $6.67 \%$ to $26.67 \%$ for Modern Strawberry-5. In in vitro clonal propagation of strawberry, MS medium supplemented with growth regulators combination of $1.0 \mathrm{mgL}-1 \mathrm{BAP}$ and $1.0 \mathrm{mgL}-1$ Kin may be the best for shoot multiplication and between the two varieties, BARI Strawberry-1 may perform better in respect of both in vitro multiplication and ex vitro survivability.

\section{ACKNOWLEDGEMENT}

The author would like to express her deepest sense of gratitude and most sincere appreciation to the authority of Plant Breeding and Biotechnology Laboratory, Agrotechnology Discipline, Khulna University, Khulna-9208 for the financial support to carry out this study successfully.

Open Access: This is an open access article distributed under the terms of the Creative Commons Attribution 4.0 License, which permits unrestricted use, distribution, and reproduction in any medium, provided the original author(s) if the sources are credited. 


\section{REFERENCES}

Biswas, M.K., Islam, R. and Hossain, M. (2007). Virus free plantlet production of strawberry through meristem culture. World Journal of Agricultural Sciences, 3(6): 757-763.

Gomez, K.A. and Gomez, A.A. (1984). Statistical procedures for agricultural research. Int. Rice Res. Inst., John Wiley and Sons. New York, Chichester, Brisbane, Toronto, Singapore. pp. 680.

Hasan, M.N., Nigar, S., Rabbi, M.A.K., Mizan, S.B. and Rahman, M.S. (2010). Micropropagation of strawberry (Fragaria $\times$ ananassa Duch.). International Journal of Sustainable Crop Production, 5(4): 36-41.

Karhu, S. and Hakala, K. (2007). Micropropagated Strawberries on the field. Acta Horticulturae, 567, 321-324.

Kosar, M. and Mahmoud, O. (2013). Regeneration and histological of plants derived from leaf explants in vitro culture of strawberry. International Journal of Agriculture and Crop Sciences, 5 (9): 943-950.

Manganaris, G.A., Goulas, V., Vicente, A.R., Terry, L.A. (2014). Berry antioxidants: small fruits providing large benefits. Journal of the Science of Food and Agriculture, 94 (5): 825-33.

Moradi, K., Otroshy, M. and Azimi, M.R. (2011). Micropropagation of strawberry by multiple shoots regeneration tissue cultures. Journal of Agricultural Technology, 7(6): 1755-1763.

Mozafari, A. and Gerdakaneh, A. (2012). Influence of media and growth regulators on regeneration and morphological characteristics of strawberry cvs Kurdistan and Merck (Fragaria ananassa Duch.). International Journal of Plant Physiology and Biochemistry, 4(5): 99-104.

Murashige, T. and Skoog, F. (1962). A revised medium for rapid growth and bioassays with tobacco tissue cultures. Journal of Plant Physiology, 15: 473-497.

Rahman, M.W., Zohora, S., Talukder, M.A.I. and Kayess, M.O. (2015). Effect of different hormone combinations on callus induction and plant regeneration of strawberry. International Journal of Advanced Research, 3 (6): 1244-1250.

Sakila, S., Ahmed, M.B., Roy, U.K., Biswas, M.K., Karim, R., Razvy, M.A., Hossain, M., Islam, R. and Hoque, A. (2007). Micropropagation of Strawberry (Fragaria $\times$ ananassa Duch.) $A$ newly introduced crop in Bangladesh. American-Eurasian Journal of Scientific Research, 2 (2): 151-154.

Swartz, H.J., Galletta, G.J. and Zimmerman, R.H. (1981). Field performance and phenotypicstability of tissue culture propagated strawberries. Journal of Science, 106:667-73.

Zakaria, H., Hussein, G.M., Abdel-Hadi, A., Abdel-Hadi and Abdallah, N.A. (2014). Improved regeneration and transformation protocols for three strawberry cultivars. GM Crops \& Food: Biotechnology in Agriculture and the Food Chain, 5 (1): 27-35.

Zobayer, N., Prodhan, S.H., Sikdar, S.U., Azim, F. and Ashrafuzzaman, M. (2011). Study of shoot multiplication of Strawberry (Fragaria ananassa). International Journal of Agricultural Research, Innovation \& Technology, 1(1\&2): 69-72. 